\title{
Learner-Centred Materials Development in Initial Language Teacher Education
}

\author{
Sudiran $^{1}$, Flávia Vieira ${ }^{2}$ \\ ${ }^{I}$ English Education Department/ University of Muhammadiyah Malang, Indonesia \\ ${ }^{2}$ Department of Studies in Literacy, Didactis and Supervision/University of Minho, Portugal
}

\begin{abstract}
Given the fact that teacher-centred language pedagogies prevail in many school settings, initial teacher education programmes should empower trainees to become learner-centred professionals, which includes their ability to develop learner-centred materials. However, not much is known about how those programmes incorporate materials development with a view to promote learner autonomy. This paper presents a small-scale qualitative study in a university programme that prepares teachers of English as a foreign language for secondary schools. Learner-centred materials design and implementation is part of the programme and the purpose of the study was to investigate its value and shortcomings in professional learning and innovation for autonomy. Data was collected through interviews, classroom observation and the analysis of practicum portfolios. Results indicate that trainees believe in and seek to develop learner-centred materials and autonomy-oriented teaching, although constraints are identified relating to their background experience, the unpredictability of practice, and dominant pedagogic cultures in school. Learner-centred teaching appears to be a crucial yet demanding task for inexperienced teachers, requiring supervisor support and a compromise between mainstream practices and a drive to innovate. A framework based on an empowering vision of language (teacher) education is proposed for enhancing learner-centred materials development.
\end{abstract}

Keywords: Learner-centred materials, Autonomy-oriented teaching, Initial teacher education

\section{Introduction}

Autonomy in language education has long been researched and accounts of autonomy-oriented approaches in diverse contexts show positive effects on the quality of teaching and learning ([1]; [2]; [3]; [4]; [5]; [6]; [7]; [8]). Nevertheless, pedagogy for autonomy is not a mainstream approach in schools, mostly due to transmission-oriented teaching traditions and structural constraints like large classes or language-focused curricula. It is not mentioned in a recent historical account of English Language Teaching (ELT) from a British and European perspective [9], which indicates its marginal status as a methodological trend. Moreover, there is no evidence to suggest that preparing teachers to develop pedagogy for autonomy has become a priority in initial teacher education (ITE) and popular coursebooks for language teacher training appear to contain little or no information about it [10].

Given the fact that teacher-centred language pedagogies still prevail in many school settings, teacher education programmes should help teachers become learner-centred professionals who value learner autonomy as an educational goal [11]. Pedagogic materials - here defined as written, spoken and visual resources that incorporate or are used along with any kind of learning activity - can foster learner-centredness since materials 'are an embodiment of the aims, values and methods of the particular teaching/ learning situation' [12]. Materials development is an important element of the professional expertise of foreign language teachers as curriculum developers ([13]; [14)) and it has been incorporated into teacher education programmes ([15]; [16]; [17]; [18]). Nevertheless, not much is known about how learner-centred materials have been explored in ITE so as to enhance autonomy-oriented teaching in schools.

This paper refers to a small-scale qualitative case study undertaken in 2015/16 within an ITE programme offered in a public university in Portugal - a two-year Master Degree in Teaching English and Spanish. In order to become teachers, students have to complete a three-year undergraduate degree in language and then a master degree that incorporates language and educational training as well as a practicum in local schools. The programme where the study took place integrates a course on learner-centred materials and the development of autonomy-oriented action research projects in the practicum. The study involved two trainees of English as a foreign language who were attending the programme, their school supervisor, and the tutor of the university-based course. Data were collected from interviews to participants, lesson observation and a selective analysis of practicum portfolios. Our purpose was to better understand the value and shortcomings of learnercentred materials in professional learning and innovation for autonomy within the programme. 


\section{Developing Learner-centred Materials}

As pointed out before, pedagogy for autonomy is not a mainstream practice in many school settings, and this is the case of Portugal where attempts to explore autonomy in language classrooms are rather scarce [19]. Nevertheless, learner autonomy has gained prominence in language policies and research all over the world, and it is one of the topics in the literature on ELT materials ([20]; [21]; [22]). Pedagogy for autonomy can take various forms, but it is essentially about centring teaching on learning with a view to enhancing learner empowerment, which entails promoting students' responsibility for learning, reflection about language and the language learning process, knowledge of and experimentation with language learning strategies, self/ comanagement of tasks, cooperation, formative (self)evaluation, and also the use of classroom data so as to improve teaching and learning [23]. It goes counter to transmission-oriented teaching and it involves the development of both communicative and learning competences in the classroom.

Materials development is an essential component of pedagogy for autonomy. Even though language coursebooks are invaluable core materials, they are aimed at large audiences and designed according to predefined purposes, which means that they are not necessarily culture-sensitive and aligned with innovative educational approaches or teachers' views of teaching. Therefore, they should be used flexibly and supplemented with other materials, which requires (prospective) teachers to develop a critical stance towards the relation between materials, instructional purposes, cultural settings and learner factors. However, there is no consensus regarding criteria for evaluating and designing materials: what vision of language education should materials embody and enhance? Since 'Any set of language teaching materials is an implicit statement about the nature of language learning' [12: 38], materials development may refer to diverse assumptions regarding language education, with implications on how it is explored in teacher education settings. As teacher educators we advocate the need to enhance a view of language education that fosters teacher and learner autonomy as a pedagogical and political educational goal [23]. ITE should then encourage the use of materials that make learning an empowering experience for learners by offering opportunities for initiative and choice, strategic learning, and awareness of learning and teaching ([21]; [22]; [20]), and also an empowering experience for novice teachers as they develop a critical stance towards transmission-oriented education and learn to make decisions that favour learner engagement. In practicum settings, teacher empowerment can be supported by inquiry-oriented teaching and dialogic supervision [24], or rather 'superVision', 'a term that denotes a common vision of what teaching and learning can and should be' [25: 8] and also 'the visionary potential of collegial relations between an insider and an outsider in which both may benefit if both take an educative/inquisitive stance' [26: 87].

Table 1 summarizes a framework developed by the second author to guide learner-centred materials analysis and design in ELT, which has been used in the programme where the study took place. The framework integrates four dimensions of learner-centredness that can be identified in the autonomy literature: contextsensitiveness, relevance of learning, reflection, and participation and social responsibility. It focuses on the quality of learning activities that are incorporated in or used along with teaching resources (texts, pictures, videos, etc.). Therefore, our concern is not with resources per se but rather with the ways in which they are used to enhance communicative and learning competences.

Table 1 Framework for Learner-Centred Materials Analysis and Design.

\begin{tabular}{|l|cl|}
\hline Dimensions & Learning activities incorporated in/ used along with teaching resources... \\
\hline Context-sensitiveness & $\bullet$ & $\begin{array}{l}\text { are appropriate to the students (age, learning level, previous knowledge, interests, needs, } \\
\text { expectations...) and to the learning situation (time available, relation with previous learning...) } \\
\text { cater for diversity and allow for differentiated learning }\end{array}$ \\
\hline Relevance of learning & - & $\begin{array}{l}\text { promote meaningful learning (realistic, personalised, connected with learner experience...) } \\
\text { promote learning that is relevant for language acquisition and use, for other subjects or life situations } \\
\text { provide or elicit proposals for future work (expansion or remediation) }\end{array}$ \\
\hline Reflection & - & $\begin{array}{l}\text { promote reflection on language (metalinguistic/ communicative awareness) and on language learning } \\
\text { processes (learning experiences, difficulties, strategies, styles, habits...) }\end{array}$ \\
\hline Participation and & promote self-evaluation (teaching and learning processes and outcomes) \\
social responsibility & $\begin{array}{l}\text { - } \\
\text { encourage students to search for and use learning resources } \\
\text { promote cooperative learning } \\
\text { foster participation in pedagogical work (initiative, choice, decision-making...) }\end{array}$ \\
\hline
\end{tabular}

Learner-centred materials development may support 'becoming-appropriate methodology', that is, methodology that seeks to be(come) sensitive to classroom cultures and 'needs to incorporate both how to teach and learning about how to teach' [27: 164], requiring action research processes whereby learning about what happens in the classroom informs teaching. This means that teachers need to be reflective practitioners who inquire into practice and adjust it to classroom circumstances. 


\section{The Study}

In this section we present the setting (3.1) and the participants (3.2) of the study, as well as its research questions and data collection procedures (3.3).

\subsection{Background Setting}

The study was developed as a post-doctorate project led by the first author with the supervision and collaboration of the second author at her institution, during the third semester of a two-year ITE programme - a Master Degree in Teaching English and Spanish-, with a focus on the ELT. During the third semester, trainees attend a practical course on ELT materials analysis and design that runs for 15 weeks (45 contact hours), in parallel with the initial stage of the practicum. The practicum takes place in the third and fourth semesters with the supervision of an experienced English teacher at school and a university-based EFL teacher educator.

The course on ELT materials development draws on previous theoretical training provided in a course on ELT methodology in the first semester of the programme, and the framework presented in Table 1 above is used by trainees to design learner-centred materials for practicum projects. The course seeks to develop a critical understanding of pedagogical, cultural and ideological roles of instructional materials, with reference to national and European language policies, namely the Common European Framework of Reference for Languages [28] in the latter case, and also to theoretical advances in the field of language education with a focus on autonomy, understood as a personal competence involving self-direction, social responsibility and critical awareness, but also as a collective interest and a democratic ideal, which means that pedagogy for autonomy entails a vision of education as (inter)personal empowerment and social transformation [23]. While this course shares common features with other training proposals, namely its reflective orientation and the relation between theory and practice [17], its distinctive feature is that it is explicitly grounded on a view of language education for autonomy, which determines the direction of innovation and the nature of trainees' professional learning.

Innovation in this setting involves the exploration of pedagogy for autonomy during the practicum, which takes place in local schools. Trainees are supported by school and university supervisors in designing a small-scale, autonomy-oriented action research project that is implemented in one of the school supervisor's classes for around 25 teaching hours. The development of action research projects involves the following steps:

- Analysis of the pedagogical context so as to identify a topic for inquiry (e.g. raising students' awareness of cultural diversity; responding to diversity in the classroom...);

- Design of a project proposal involving learner-centred strategies and materials focused on communicative and learning competences, as well as classroom data collection;

- Project implementation and on-going reflection on practice based on observation, supervision conferences, data collection/analysis, and portfolio writing (portfolios include trainees' teaching philosophy and the project proposal, a selection of lesson plans and materials, reflections on teaching, and a general appreciation of the practicum experience);

- Production of a final project report defended in a public viva.

In this practicum model, practitioner research is understood as an empowering professional development strategy that can enhance educational change ([29]; [30]; [31]; [32]). Since mainstream teaching in schools is not autonomy-oriented, pedagogy for autonomy is understood as a 're(ide)alistic' practice where possibilities for change are explored in the interspace between reality and ideals [23]. This involves, among other things, using the coursebook flexibly and adapting or designing materials so as to reach the desired outcomes.

\subsection{Participants}

The study involved four participants: MAM, the university tutor responsible for the course on materials development, who has been a teacher educator for more than 20 years and is also the programme director; MP, a school supervisor who has been a language teacher for more than 20 years; MF and CS, two young ELT trainees who were attending MAM's course on materials development and doing their practicum in MP's school, in two classes of $8^{\text {th }}$ grade students who had been learning English for three years (since grade 5). MF held a graduate degree in Language and had no previous teaching experience; his project focused on promoting students' awareness of cultural diversity through the use of music. CS held a graduate degree in Language Teaching and had some ELT experience in primary schools; her project focused on diversifying learning activities so as to respond to students' learning styles.

The second author was the trainees' university supervisor, which facilitated access to the research context and data collection. She informed the participants about the study and invited them to collaborate, which they accepted, giving their permission to use the data collected. 


\subsection{Research Questions And Data Collection}

The study inquired into the role of learner-centred materials in professional learning and innovation for autonomy. Three research questions were set:

1. What are the participants' views of foreign language pedagogy and the role of materials in foreign language learning?

2. To what extent are the ELT materials designed by the trainees learner-centred?

3. What constraints affect the design and use of learner-centred ELT materials?

A qualitative approach was used, involving three sequential data collection procedures whose foci are summarized in Table 2: (1) individual, structured interviews to the four participants, conducted in English, taperecorded and transcribed (December 2015); (2) non-participant observation of two project lessons taught by the trainees in school (February 2016); (3) selective content analysis of the trainees' practicum portfolios (collected at the end of the practicum in June 2016; excerpts used in the paper were translated into English). Data analysis involved the triangulation of sources and voices with reference to the research questions above.

Table 2 Research Foci.

\begin{tabular}{|l|l|l|l|}
\hline Foci of research questions & Foci of interviews ${ }^{*}$ Foci of lesson observation & Foci of portfolio analysis \\
\hline $\begin{array}{l}\text { Views of foreign language } \\
\text { pedagogy and the role of } \\
\text { materials }\end{array}$ & $\begin{array}{l}\text { Goals of foreign language } \\
\text { teaching and learning } \\
\text { Importance of coursebooks and } \\
\text { materials design } \\
\text { Factors to consider in materials } \\
\text { design }\end{array}$ & & $\begin{array}{l}\text { Views on foreign language } \\
\text { teaching and learning }\end{array}$ \\
\hline $\begin{array}{l}\text { Extent to which trainees } \\
\text { materials are learner- } \\
\text { centred }\end{array}$ & $\begin{array}{l}\text { Extent to which materials } \\
\text { designed are learner-centred and } \\
\text { why }\end{array}$ & $\begin{array}{l}\text { Use of materials } \\
\text { (effectiveness in terms of } \\
\text { learner response) }\end{array}$ & $\begin{array}{l}\text { Materials produced } \\
\text { Perceptions about the use of } \\
\text { materials }\end{array}$ \\
\hline $\begin{array}{l}\text { Constraints to materials } \\
\text { design and use }\end{array}$ & $\begin{array}{l}\text { Difficulties in materials design } \\
\text { and use }\end{array}$ & $\begin{array}{l}\text { (effectiveness in terms of } \\
\text { learner response) }\end{array}$ & materials \\
\hline
\end{tabular}

(*) Interview questions to trainees and supervisors were equivalent, e.g.: Do you think it is it important that you use the coursebook in class? Why/not? (trainees) / Do you think it is it important that trainees use the course book in class? Why/not? (supervisors).

\section{Findings}

Findings related to the three research questions are presented below, focusing on participants' views of language pedagogy and instructional materials (4.1), the use of learner-centred materials (4.2), and perceived constrains to learner-centred materials development (4.3).

\subsection{Views of Language Pedagogy And Materials}

Overall, interviews and portfolios account for a conception of foreign language pedagogy as a space for enhancing students' communicative and learning competences, and also as a space for inquiry-based professional development ([23]; [31]).

The school supervisor and the course tutor see language teaching as a means to promote students' communicative and cultural competences, which is in tune with the national syllabus, and the course tutor further refers to developing 'autonomous learners that will be able to keep on learning the language even though they are not in school anymore' (MAM, interview). Trainees' accounts from the interviews focus on pragmatic goals like preparing students to communicate with English speakers and to travel, apply for a job or a scholarship abroad, and MF mentions the status of English as an international language that students should be able to use so as to 'communicate with the world' (MF, interview). However, their portfolios account for a view of language education that goes far beyond these pragmatic goals. In his portfolio, MF assumes that language education should promote democratic citizenship through intercultural competence (MF, portfolio: 7) and he sets the following action research objectives:

1. Assessing students' knowledge, needs and interests in foreign language learning;

2. Sensitising students to cultural diversity towards the development of intercultural competence through the use of music;

3. Developing students' autonomy through reflection on learning;

4. Evaluating the impact of the approach with a focus on intercultural competence.

As for CS, she states that 'we need to rethink the teacher's role so that classes become truly inclusive, respond to diversity in the classroom and contribute to promote students' autonomy and awareness of their own learning process' (CS, portfolio: 4), and she sets the following project objectives:

1. Assessing students' learning competences and needs; 
2. Identifying students' learning intelligences and styles;

3. Developing activities that respond to diversity in class taking into account the dominant learning needs and styles of the students;

4. Evaluating the impact of those activities on students' involvement and performance.

The trainees' project proposals, presented in the portfolios, are grounded on a context-sensitive, autonomy-oriented view of language pedagogy where materials design is seen to play a crucial role. Trainees value the use of coursebooks, but they also believe that materials development is a necessary component of learner-responsive teaching, allowing teachers to adjust to learner needs, to increase information input and exposure to authentic language, and to promote engagement in learning:

'When I design my materials, I focus on the students' needs. (...) For me it is very difficult to create the materials, but in the end I can focus on the needs of the students. That is why it is very important.' (MF, interview)

'Students are very different from one another so they learn in very different ways, and if we explore different media we will get the most appropriate materials for the class and we will use the adequate teaching method. The students will be more motivated and engaged in their learning process.' (CS, interview)

The supervisor and the course tutor agree that trainees are encouraged and supported to develop learner-centred teaching through using the framework presented in Table 1 and developing autonomy-oriented action research projects in school. The value and shortcomings of learner-centred materials in professional learning and innovation become more evident in the following sections.

\subsection{ELT Materials And Learner-Centred Teaching}

In the interviews, participants agree that an effort is made to use learner-centred materials as expected in the programme, and the fact that materials design within the university-based course is directly connected with practice appears to reinforce a focus on the quality of learning (cf. [17]; [18]). This is quite evident in how trainees reflect about the (in)effectiveness of materials in their portfolios. Table 3 indicates the occurrence of learning-oriented concerns inferred from written reflections about the three lessons each trainee selected to illustrate their project in portfolios, in a total of six reflections.

Table 3 Learning-Oriented Concerns (portfolio reflections).

\begin{tabular}{|l|l|l|l|}
\hline Concerns inferred from portfolio reflections $(n=6)$ & $M F$ & $C S$ & Total \\
\hline Manage time effectively so as to facilitate learning & 3 & 3 & 6 \\
\hline Increase opportunities for communication & 3 & 3 & 6 \\
\hline Promote participation and engagement & 3 & 3 & 6 \\
\hline Foster reflection on learning & 2 & 3 & 5 \\
\hline Develop intercultural awareness and competence & 3 & 1 & 4 \\
\hline Adjust contents and activities to learner needs, interests and styles & 1 & 3 & 4 \\
\hline
\end{tabular}

Learner-centredness was also evident in the two lessons observed. We will take the case of MF's lesson, whose plan is presented in Table 4 (adapted from his plan). The right-hand column was added to indicate learner-centred criteria from the framework presented in Table 1 above. These criteria relate to the four framework dimensions of learner-centredness: context-sensitiveness (CS), relevance of learning (RL), reflection $(\mathrm{R})$, and participation and social responsibility (PSR). The criteria were inferred on the basis of the lesson plan and lesson observation. According to observation notes, the lesson appeared to be appropriate to the students' interests, promoting linguistic, cultural and learning competences. Overall, students looked attentive, motivated and engaged. They had the opportunity to work collaboratively and asked questions when they had doubts. They were able to understand and complete the activities and made an effort to use the target language.

As shown in Table 4 (right-hand column), a concern with context-sensitiveness and the relevance of learning is evident, but also with developing students' metacognitive awareness through self-evaluation. The self-evaluation questionnaire used in this lesson was specifically designed for the project and consisted of three closed questions (1-3) and two open-ended questions (4-5):

1. Did you enjoy the music we listened to?

2. Did the activities help you understand the content of the song?

3. Did the activities help you understand aspects related with our project (multiculturalism, cultural diversity, intercultural communication)?

4. Considering the work you have done, what message would you like to tell the world?

5. Write any comments about the activities, e.g., what you liked most or least, difficulties you felt. 
Table 4 Learner-Centred Practice (MF's lesson).

\begin{tabular}{|c|c|c|}
\hline $\begin{array}{l}\text { Topic area: intercultural awareness } \\
\text { Time: } 45\end{array}$ & \multicolumn{2}{|c|}{$\begin{array}{l}\text { Project objectives: expand awareness of cultural diversity, develop learner autonomy, } \\
\text { evaluate the impact of teaching }\end{array}$} \\
\hline \multicolumn{3}{|c|}{ Communicative competences: develop intercultural awareness, interact to discuss own ideas and opinions } \\
\hline \multicolumn{3}{|c|}{ Learning competences: become aware of the teaching/learning process } \\
\hline Learning activities & Supporting resources & Learner-centred criteria (cf. Table 1) \\
\hline $\begin{array}{l}\text { Pre-listening } \\
\text { After recalling previous lesson topics related to } \\
\text { multiculturalism, T elicits Ss' previous knowledge about } \\
\text { the song Black or White and the singer so as to } \\
\text { anticipate the lesson topic (racial issues). }\end{array}$ & $\begin{array}{l}\text { Whiteboard: title of a well- } \\
\text { known song by Michel } \\
\text { Jackson: Black or White }\end{array}$ & $\begin{array}{l}\text { promoting meaningful learning (connected with } \\
\text { learner experience) }[\mathrm{RL}]\end{array}$ \\
\hline $\begin{array}{l}\text { Listening } \\
\text { Ss listen to the song as they watch the videoclip and fill } \\
\text { in the lyrics with missing words; T checks Ss' work } \\
\text { orally and writes the missing words on the board. }\end{array}$ & $\begin{array}{l}\text { Handout: lyrics of the song } \\
\text { with missing words } \\
\text { Computer and projector: } \\
\text { videoclip } \\
\text { Whiteboard: missing words }\end{array}$ & $\begin{array}{l}\text { promoting learning that is relevant for language } \\
\text { use [RL] }\end{array}$ \\
\hline $\begin{array}{l}\text { Post-listening } \\
\text { In pairs, Ss use the missing words to write a sentence } \\
\text { that relates to the message of the song and some pairs } \\
\text { present their ideas to the class. } \\
\text { Ss observe two photos of Michael Jackson (from his } \\
\text { youth and adulthood) and express opinions about 'what } \\
\text { made Michael Jackson change his colour'; T provides } \\
\text { input on the singer's life story. }\end{array}$ & $\begin{array}{l}\text { Handout: lyrics of the song } \\
\text { Whiteboard: missing words } \\
\text { Computer and projector: two } \\
\text { photos of Michael Jackson }\end{array}$ & $\begin{array}{l}\text { promoting learning that is relevant for language } \\
\text { use and life situations [RL] } \\
\text { promoting cooperative learning [PSR] } \\
\text { promoting meaningful learning (realistic, } \\
\text { connected with learner experience) [RL] } \\
\text { catering for diversity and allowing for } \\
\text { differentiated learning [CS] }\end{array}$ \\
\hline $\begin{array}{l}\text { Self-evaluation } \\
\text { Ss fill in a self-evaluation questionnaire; T collects } \\
\text { questionnaires to evaluate teaching }\end{array}$ & $\begin{array}{l}\text { Self-evaluation } \\
\text { questionnaire }\end{array}$ & $\begin{array}{l}\text { promoting self-evaluation }[\mathrm{R}] \\
\text { fostering participation in pedagogical work } \\
\text { [PSR] }\end{array}$ \\
\hline
\end{tabular}

T - Teacher; Ss - Students

Both portfolios account for the use of materials that connect curriculum contents with students' experience and ideas as illustrated by MF's lesson, an aspect that was rather absent from coursebook proposals. However, the most innovative aspect of trainees' materials is the promotion of learner reflection and the collection of learner data to analyse teaching and learning processes. Learner reflection materials expand students' voice, allowing them to develop self-evaluation skills and metacognitive awareness [22], participate in the evaluation of teaching, and eventually influence subsequent teaching decisions. Teachers can collect students' reflections and analyse data, which allows them to reflect on and improve teaching and learning processes.

Table 5 indicates the foci of learner reflection materials presented in the trainees' portfolios. These materials were designed by them with the help of supervisors. Closed and open-ended questions were posed to the students so as to elicit reflection on learning experiences, attitudes, preferences, styles and expectations, as well as on teaching approaches. Nevertheless, reflection can also serve other purposes, namely assessment for learning by involving students in planning, monitoring and assessing specific language tasks [18]. Actually, opportunities for self-management of learning were rather absent from the trainees' approach, although comanagement of learning was enhanced through dialoguing with students about learning and using data from reflection materials to assess and revise teaching.

Table 5 Learner Reflection Materials (portfolios).

\begin{tabular}{|l|l|l|}
\hline Materials & MF's project: Students reflect on... & CS's project: Students reflect on... \\
\hline $\begin{array}{l}\text { Initial } \\
\text { questionnaire } \\
\text { getting to know the } \\
\text { students) }\end{array}$ & $\begin{array}{l}\text { attitudes and motivation towards learning English } \\
\text { preferences regarding music and target-culture } \\
\text { potential value of music in language learning } \\
\text { willingness to use music in English lessons }\end{array}$ & $\begin{array}{l}\text { personal learning intelligences } \\
\text { attitudes and motivation towards learning English } \\
\text { difficulties in previous language learning } \\
\text { preferences regarding language learning activities }\end{array}$ \\
\hline $\begin{array}{l}\text { Monitoring } \\
\text { questionnaires } \\
\text { (used after lesson } \\
\text { sequences) }\end{array}$ & $\begin{array}{l}\text { receptiveness towards the songs used in class } \\
\text { usefulness of activities for intercultural learning } \\
\text { personal values regarding lesson topics } \\
\text { difficulties felt during activities }\end{array}$ & $\begin{array}{l}\text { intelligences promoted through lesson activities } \\
\text { reasons why they (dis)liked activities } \\
\text { engagement, cooperation and achievement } \\
\text { difficulties felt during activities } \\
\text { how lessons might be improved }\end{array}$ \\
\hline $\begin{array}{l}\text { Final } \\
\text { questionnaire (MF) } \\
\text { and 'letter to the } \\
\text { teacher' (CS) } \\
\text { (project evaluation) }\end{array}$ & $\begin{array}{l}\text { receptiveness towards the use of music in the project } \\
\text { usefulness of the project for intercultural learning } \\
\text { personal values regarding cultural diversity } \\
\text { willingness to go on learning about other cultures } \\
\text { willingness to go on using music in class }\end{array}$ & $\begin{array}{l}\text { learning intelligences promoted by the project } \\
\text { usefulness of differentiated teaching } \\
\text { usefulness of the project for learning } \\
\text { difficulties felt during the project } \\
\text { how the project might be improved }\end{array}$ \\
\hline
\end{tabular}

${ }^{*}$ Adapt. from Armstrong, T. (2001). Inteligências múltiplas na sala de aula. Porto Alegre: Artmed. 
The students' feedback on the trainees' projects was very positive. Table 6 illustrates this with results from a final questionnaire administered by MF to his students $(n=24)$ (the questionnaire items were in the students' mother tongue). These results, presented in the trainee's portfolio, account for his students' receptiveness to the use of music in language learning and their positive perceptions of the project impact on cultural awareness.

Table 6 Final Project Evaluation Results: Example (MF's portfolio).

\begin{tabular}{|c|c|c|c|c|c|}
\hline Questionnaire items & $T D$ & $D$ & $N S$ & $A$ & $T A$ \\
\hline \multicolumn{6}{|l|}{ Receptiveness to the use of music } \\
\hline I liked to work with music in class & - & - & - & - & $100 \%$ \\
\hline Music motivated me to participate in class & - & - & - & $8,4 \%$ & $91,6 \%$ \\
\hline I liked the themes of the songs & - & - & - & $25 \%$ & $75 \%$ \\
\hline Using music helped me learn the language & - & - & - & $58,4 \%$ & $41,6 \%$ \\
\hline \multicolumn{6}{|l|}{ Development of cultural awareness } \\
\hline Lessons increased my cultural knowledge & - & - & $6,6 \%$ & $33,4 \%$ & $60 \%$ \\
\hline Activities allowed me to compare cultures & - & - & $6,6 \%$ & $53,4 \%$ & $40 \%$ \\
\hline Lessons allowed me to reflect about cultural differences & - & - & - & $46,6 \%$ & $53,4 \%$ \\
\hline I became more aware of cultural diversity in the world & - & - & - & $46,6 \%$ & $53,4 \%$ \\
\hline I learnt to value cultural knowledge for good communication & - & - & - & $50 \%$ & $50 \%$ \\
\hline I became more motivated to learn about other cultures & - & - & - & $41,6 \%$ & $58,4 \%$ \\
\hline
\end{tabular}

TD - Totally Disagree; D - Disagree; NS - Not Sure; A - Agree; TA - Totally Agree

MF' final questionnaire also included a question where students were asked to imagine that they wanted 'to write a song about cultural diversity in the world' and invent a title for it. As he writes in his portfolio, the students' titles reveal sensitiveness to cultural diversity and indicate values that enhance intercultural communication, e.g. Human Rights, A More Just World, Equality for All, No to Racism, Different Yet the Same, Social Equality, and Cultural Respect (MF, portfolio: 76-78). These ideas are important for democratic citizenship in a multicultural world, which is a central political purpose of education for autonomy.

In the case of CS, who explored diversity in the classroom, she asked students to write 'a letter to the teacher' at the end of her project, providing them with two guiding questions about the importance of catering for different learning styles in the classroom and the extent to which her project enhanced a diversified approach to language learning. Students' reflections indicate that they felt their needs and preferences were met and they realised the importance of being aware of and expanding their personal learning approaches (CS, portfolio: 87), which is an important aspect of their development as self-directed learners.

\subsection{Constraints To Learner-Centred Materials Development}

Even though training in materials design was valued by all participants and had an impact on trainees' teaching practices, constraints were also identified, relating to the trainees' lack of experience, the contingency and unpredictability of practice, and cultures of teaching. From the course tutor's perspective, trainees' previous experience as learners causes initial difficulties in grasping the meaning of learner-centredness, which signals the influence of traditional teacher-centred approaches upon prospective teachers' mindsets:

'If they were used to having a learner-centred approach while they were in high school or even at university, they would understand it much faster, that is, the meaning of innovation and learnercentredness.' (MAM, interview)

The tutor's comment refers to 'the apprenticeship of observation' [33], often associated with the idea that 'teachers teach the way they were taught' [34: 51]. Therefore, teacher education needs to challenge trainees' preconceptions and assumptions regarding teaching and learning, and this is one of the purposes of the course on materials development, where trainees learn to look critically at instructional proposals with reference to the notion of learner-centredness.

Trainees further stress their lack of teaching experience as an important constraint to materials design and implementation. They see materials design as a time-consuming task that involves a lot of searching and revising, and they express uncertainties regarding students' reactions to materials and the adequacy of materials to instructional goals:

'I am speaking about multiculturalism and intercultural issues. So I think this is very hard for students in that grade to understand quickly. (...) when I implement my materials, the most difficult thing is to make students understand what I am teaching and what I want for them.' (MF, interview)

'I am not sure whether the materials are relevant to the students or not. (...) I become a little bit nervous because I do not know how students will react to the materials. I do not know whether the materials fulfil the objectives or not.' (CS, interview) 
The school supervisor also points out the unpredictability of materials-in-use as the trainees' main source of concern:

'This is the main aspect of the trainees' difficulties, that they are not aware of the consequences. They are experimenting. They are innovating and such a process always generates some anxiety or curiosity, but it is part of the learning process.' (MP, interview)

The contingent nature of practice is evident in portfolio reflections about the two observed lessons. Trainees refer to how unclear instructions in one of the tasks may have caused students to feel at lost and not accomplish it appropriately, how the superficial exploration of supporting resources may have reduced opportunities for learning, how students' unfamiliarity with the topic may have lowered their engagement is some activities, and how poor time management resulted in limited time for reflection on learning at the end of the lesson.

The unpredictability of pedagogical work is partly related to the lack of teaching expertise, which is an important factor to consider in ITE contexts, but also to the necessary interplay between structure and process in exploratory teaching, which means that tensions arise between the planned and predictable and the improvised and unpredictable [35]. Exploratory teaching involves careful planning that allows 'enough room to innovate and move in novel directions for learners to develop autonomy and fuel their intrinsic motivation' [35: 53]. Trainees' insecurities can therefore result from exploring learner-centred teaching where teacher control is reduced and activities tend to be more open-ended and dialogic.

Uncertainties regarding practice also highlight the complexity of classroom cultures and the developmental nature of 'becoming-appropriate methodology' based on a continuous dialogue between teaching and learning through classroom-based inquiry [27]. Actually, 'the control that teachers exercise in the learning process is underwritten and constrained by broader structures of power' [36: 32]. The course tutor points out that school policies and routines regarding department planning, the use of coursebooks and external assessment may reduce trainees' autonomy to enact change (MAM, interview). This may also explain why certain aspects of autonomy were less explored, namely the involvement of students in decision-making regarding what to learn and how. Moreover, even though the practicum model values inquiry and innovation, the time available for project implementation is rather limited. In the portfolios, trainees point out that this reduces their opportunities to develop and assess learner-centred approaches. Despite this constraint, they believe they became learnercentred teachers. In a final appreciation of project development, MF expresses his intention to go on promoting activities that meet students' needs and interests, enhance their intercultural competence, and involve them in reflection and decision making so as to develop autonomy (MF, portfolio: 86); CS reinforces the need to differentiate teaching approaches and increase students' awareness of learning so as to respond to diversity in the classroom and ensure both motivation and successful learning (CS, portfolio: 88).

\section{Conclusion}

Although the study is local and exploratory, which limits the significance of results, it suggests that ITE practices drawing on an autonomy-oriented rationale can support the development of prospective teachers' identity as learner-centred professionals. When materials design is directly connected with projects that aim at learner engagement ([22]; [21]), teachers will find opportunities to scrutinize and reshape dominant teaching practices ([16]; [18]). However, constraints to innovative materials development are pointed out, relating to the trainees' lack of professional experience and their past experience as learners, uncertainties regarding materials appropriateness to student learning, and also educational policies and cultures that reduce possibilities for change. This is why 'superVision' based on dialogue and inquiry can assist professional empowerment by allowing teachers to explore possibilities for innovation in a supportive environment ([24]; [25]; [26]).

An implication of the study is that ITE institutions and schools should act as interconnected learning sites where trainees are empowered to explore learner-centred pedagogies by reconciling established cultures and policies with a drive to innovate. This idea is represented in Fig. 1, where a framework for learner-centred ELT materials development in ITE programmes is proposed. In this scenario, materials development is inspired by ideals of empowerment and transformation, but also influenced by local and national policies and traditions of teaching and teacher education, which means that innovation is often modest. Approaches to autonomy may become depoliticized or politically ambiguous due to 'a shift from a concern with situational and external aspects of autonomy to a focus on psychological and internal capacities' [36: 39]. Structural constraints are often unsurmountable and disempower teachers, reducing the scope and impact of change. 


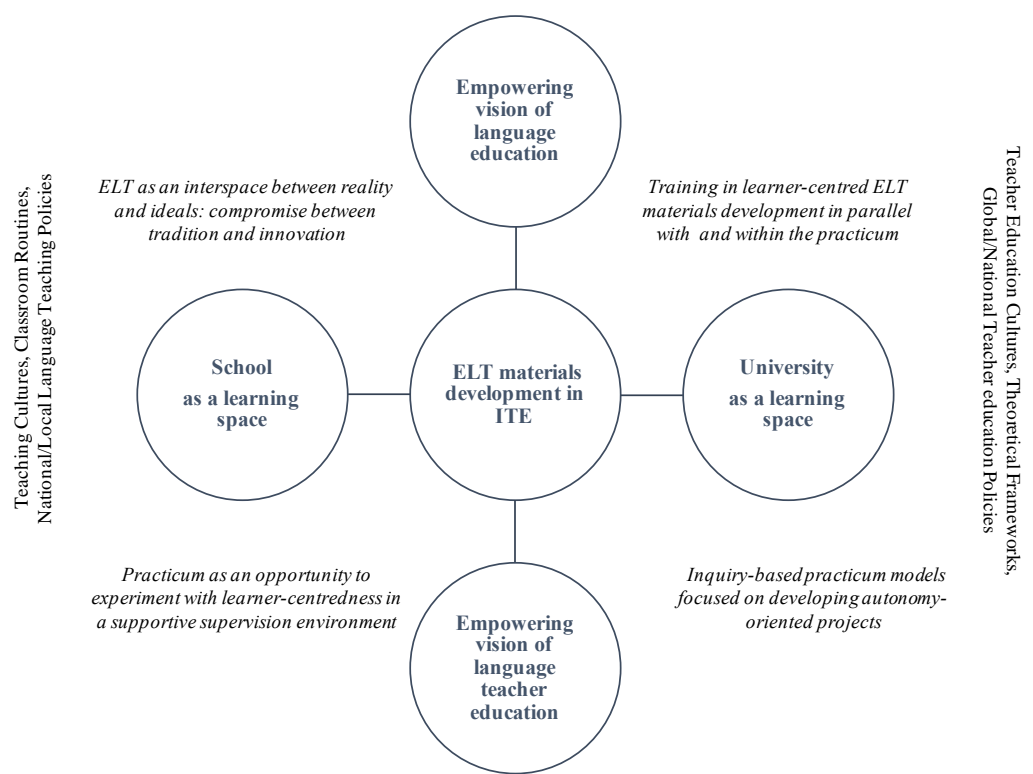

Figure 1 Framework for Learner-Centred ELT Materials Development in ITE.

It is a fact that the projects developed in this programme are isolated, small-scale and exploratory, primarily focused on students' learning, and constrained by school cultures where professional inquiry and innovation are the exception rather than the rule ([31]; 37]). Even though this reduces the scope and impact of professional learning and educational change, exploring possibilities between reality and ideals can become a springboard for transformation. We thus need more accounts on how training in learner-centred materials development can be connected with autonomy-oriented teaching within ITE programmes.

\section{Acknowledgements}

The authors wish to thank the participants for collaborating in the study, which was supported by Swap and Transfer Erasmus Mundus - Action 2 Mobility Lot 12 (Grant awarded to the first author, Contract SAT_2388 under Project No. 20132537/001-EMA2), and by CIEd - Research Centre on Education, projects UID/CED/1661/2013 and UID/CED/1661/2016, Institute of Education, University of Minho, through national funds of FCT/MCTES-PT.

\section{References}

[1]. R. Pemberton, E.S.L. Li, W.W.F. Or, and H.D. Pierson (Eds.), Taking control: Autonomy in language learning (Hong Kong: Hong Kong University Press, 1996).

[2]. D. Palfreyman and R. Smith (Eds.), Learner autonomy across cultures - Language education perspectives (Houndmills: Palgrave Macmillan, 2003)

[3]. A. Barfield and S. Brown (Eds.), Reconstructing autonomy in language education - Inquiry and innovation (Houndmills: Palgrave Macmillan, 2007).

[4]. M. Jiménez Raya and T. Lamb (Eds.), Pedagogy for autonomy in language education - Theory, practice and teacher education (Dublin: Authentik, 2008).

[5]. T. Lamb and H. Reinders (Eds.), Learner and teacher autonomy: Concepts, realities, and responses (Amsterdam: John Benjamins, 2008).

[6]. F. Vieira (Ed.), Struggling for autonomy in language education - Reflecting, acting, and being (Frankfurt am Main: Peter Lang, 2009).

[7]. Ph. Benson, Teaching and researching autonomy in language learning (2nd edition) (London: Longman, 2011).

[8]. A. Barfield and N.D. Alvarado (Eds.), Autonomy in language learning: Stories of practices (Canterbury: IATEFL Learner Autonomy SIG, 2013).

[9]. A.P.R. Howatt and R. Smith, The history of teaching English as a foreign language, from a British and European perspective, Language \& History, 57(1), 2014, 75-95.

[10]. H. Reinders and C. Balcikanli, Learning to foster autonomy: The role of teacher education materials, Studies in Self-Access Learning Journal, 2(1), 2011, 15-25.

[11]. M. Jiménez Raya and F. Vieira, Enhancing autonomy in language education: A case-based approach to teacher and learner development (Berlin/ New York: Mouton de Gruyter, 2015).

[12]. T. Hutchinson, What's underneath? An interactive view of materials evaluation, in L. Sheldon (Ed.), ELT textbooks and materials: Problems in evaluation and development (London: Modern English Publications in association with The British Council, 1987) 3744.

[13]. I. McGrath, Teaching materials and the roles of EFL/ESL teachers: Practice and theory (London: Bloomsbury, 2013).

[14]. B. Tomlinson, The importance of materials development for language learning, in M. Azarnoosh, M. Zeraatpishe, A. Faravani, and H.R. Kargozari (Eds.), Issues in materials development (Rotterdam: Sense Publishers, 2016) 1-10. 
[15]. M. Wyatt, Becoming a do-it-yourself designer of English language teaching materials, Forum: Qualitative Social Research 12(1), 2011, Retrieved from http://nbn-resolving.de/urn:nbn:de:0114-fqs1101334.

[16]. A.N. Pardo and M.F.T. Téllez, Reflection on teachers' personal and professional growth through a materials development seminar. How, 22(2), 2015, 54-74.

[17]. M. Bouckaert, Designing a materials development course for EFL student teachers: Principles and pitfalls, Innovation in Language Learning and Teaching, 10(2), 2016, 90-105.

[18]. E. Edwards and A. Burns, Action research to support teachers' classroom materials development, Innovation in Language Learning and Teaching, 10/2, 2016, 106-120.

[19]. F. Vieira, M.A. Moreira, and H. Peralta, Research in foreign language education in Portugal (2006-2011): Its transformative potential, Language Teaching, 47, 2014, 191-227.

[20]. B. Sinclair, Materials design for the promotion of learner autonomy: How explicit is 'explicit'?, in R. Pemberton, E.S.L. Li, W.W. F. Or, and H.D. Pierson (Eds.). Taking control: Autonomy in language learning (Hong Kong: Hong Kong University Press, 1996) $149-165$.

[21]. J. Edge and S. Wharton, Autonomy and development: Living in the materials world, in B. Tomlinson (Ed.); Materials development in language teaching (Cambridge: Cambridge University Press, 1998) 295-310.

[22]. A-B Fenner, Learner autonomy, in A-B. Fenner and D. Newby (Eds.), Approaches to materials design in European textbooks: Implementing principles of authenticity, learner autonomy, cultural Awareness (Council of Europe: European Centre for Modern Languages, 2000) 77-86.

[23]. M. Jiménez Raya, T. Lamb and F. Vieira, Pedagogy for autonomy in language education in Europe. Towards a framework for learner and teacher development (Dublin: Authentic, 2007).

[24]. D. Waite, Rethinking instructional supervision - Notes on its language and culture (London: The Falmer Press, 1995).

[25]. C. Glickman, S. Gordon, and J. Ross-Gordon, SuperVision and instructional leadership - A developmental approach (6th ed) (Boston: Pearson Education, 2004).

[26]. D. Waite, Teacher resistance in a supervision conference, in D. Corson (Ed.), Discourse and power in educational organizations (Cresskill: Hampton Press, 1995) 7-87.

[27]. A. Holliday, Appropriate methodology and social context (Cambridge: Cambridge University Press, 1994).

[28]. Council of Europe, Common European framework of reference for languages: Learning, teaching, assessment (Cambridge: Cambridge University Press, 2001).

[29]. A. Campbell, O. McNamara, and P. Gilroy, Practitioner research and professional development in education (London: Paul Chapman Publishing, 2004).

[30]. D. Burton and S. Bartlett, Practitioner research for teachers (London: Paul Chapman Publishing, 2005).

[31]. F. Vieira and M.A. Moreira, Reflective teacher education towards learner autonomy: Moving towards a culture of possibility, in M.J. Raya and T. Lamb (Eds.), Pedagogy for autonomy in language education - Theory, practice and teacher education (Dublin: Authentik, 2008) 266-282.

[32]. M. Vaughan and G. Burnaford, Action research in graduate teacher education: A review of the literature 2000-2015, Educational Action Research, 24(2), 2016, 280-299.

[33]. D. Lortie, Schoolteacher: A sociological perspective (Chicago, IL: University of Chicago Press, 1975).

[34]. R. Heaton and W.T. Mickelson, The learning and teaching of statistical investigation in teaching and teacher education, Journal of Mathematics Teacher Education, 5(1), 2002, 35-59.

[35]. L. Van Lier, Action-based teaching, autonomy and identity, Innovation in Language Learning and Teaching, 1(1), 2007, 46-65.

[36]. Ph. Benson, Concepts of autonomy in language learning, in R. Pemberton, E.S.L. Li, W.W. F. Or, and H.D. Pierson (Eds.), Taking control: Autonomy in language learning (Hong Kong: Hong Kong University Press, 1996) 27-34.

[37]. F. Vieira, I. Barbosa, M. Paiva, and I. S. Fernandes, Teacher education towards teacher (and learner) autonomy: What can be learnt from teacher development practices?, in T. Lamb and H. Reinders (Eds.), Learner and teacher autonomy: Concepts, realities, and responses (Amsterdam: John Benjamins, 2008) 217-235. 